\title{
Kosulys ir gastroezofaginis refliuksas: mechanizmai
}

\author{
Giovanni A. Fontana MD, FRCP \\ Florencijos universiteto Vidaus ligų klinikos Imunoalergologijos, kvėpavimo medicinos ir ląstelių \\ terapijos skyrius, Italija
}

\begin{abstract}
Reikšminiai žodžiai: kosulys, gastroezofaginis refliuksas, refliukso sukelto kosulio mechanizmai.
Santrauka. Kosulys yra vienas iš dažniausių nusiskundimų, dèl kurio suaugę asmenys kreipiasi i gydytoją. Gastroezofaginis refliuksas (GER) - tai skrandžio turinio grižimas i stemplę, kuris pasitaiko beveik visiems sveikiems žmonèms, tačiau dažniausiai nesukelia jokių simptomų ar diskomforto. Kai GER lydi simptomai ar diskomfortas, jis jau ne fiziologinis ir vadinamas gastroezofaginio refliukso liga. Kosulys esant refliuksui daugeliui pacientų gali būti paaiškinamas skirtingais mechanizmais. Kai kurie iš jų yra akivaizdūs (pvz., aspiracija), o kitiems reikia papildomų tyrinèjimų ir įrodymų. Neabejotinai tam tikriems pacientams skrandžio turinio aspiracija ar mikroaspiracija yra pagrindinè kosulio priežastis. Neurogeniniai mechanizmai, refleksiškai reaguojantys į stemplès sekreto parūgštejjimą, gali sukelti kvėpavimo takų pakitimus ir respiracinius simptomus, i̇skaitant kosuli. Centrinis kosulio reflekso ¡jsijautrinimas, kaip atsakas i „lètinį" stemplès gleivinès dirginimą rūgštimi ar ne rūgštimi, refliuksą patiriantiems asmenims gali būti bendras padidejjusio kosulio reflekso jautrumo genezès mechanizmas, nors ir nepriežastinis.
\end{abstract}

Kosulys yra vienas iš dažniausių nusiskundimų, dèl kurio suaugę asmenys kreipiasi i gydytoją. Paprastai kosulys būna trumpalaikis, savaime praeinantis simptomas, tačiau kai kada jis gali tapti nuolatiniu. Kosulio refleksas reguliuojamas klajoklio nervo (n. vagus), todèl gali kilti bet kurioje šio nervo eigos vietoje. Kosulys, užsitęsęs ilgiau kaip 3 savaites, laikomas lètiniu [1]; dažniausių lètinio kosulio priežastiniu veiksnių ir jų gydymo analizè yra daugelio puikių apžvalginių straipsnių ir publikuotų gairių dèmesio objektas [1-4].

Gastroezofaginis refliuksas (GER) tai skrandžio turinio grižimas ị stemplę, kuris pasitaiko beveik visiems sveikiems žmonèms, tačiau dažniausiai nesukelia jokiu simptomų ar diskomforto. Kai GER lydi simptomai ar diskomfortas, jis jau ne fiziologinis, o laikomas gastroezofaginio refliukso liga (GERL). Remiantis naujausiomis gairèmis, GERL yra tada, kai skrandžio turinio refliuksas sukelia varginančius simptomus ir/ar komplikacijas [5].

Kitas svarbus klinikinis objektas - laringofaringinis refliuksas (LFR), t. y. skrandžio turinio regurgitacija ị viršutinius kvẻpavimo ir virškinamojo trakto takus $[6,7]$. Iki šios nèra neaišku, ar LFR yra atskiras klinikinis reiškinys, kuriam būdingos tam tikros patofiziologinès ypatybès, ar tam tikra GERL išraiška, apimanti viršutinius kvėpavimo takus ir kaklo struktūras. Kadangi GER ir LFR abu gali sukelti respiracinius simptomus, kaip antai kosuli, šiame straipsnyje jie aprašomi kaip ta pati patologija.

\section{KODÉL REFLIUKSAS TOKS DAŽNAS}

GERL paplitimas stiprios ekonomikos šalyse yra apie 10-20 proc. [8]. Apžvelgus "simptominius apibrèžimus", matyti, kad GERL susijęs su padidèjusia ekstraezofaginių sindromų rizika, isskaitant lètinę obstrukcinę plaučių ligą (LOPL), astmą, lètinị kosulị, laringitą ir krūtinès skausmą [8]. Jungtineje Karalystejje atliktu tyrimu buvo nustatyta, kad diagnozavus GERL per pirmuosius metus padideja tikimybè, kad bus pirmą kartą diagnozuotas kosulys, sinusitas ar krūtinès skausmas; sąsajos su plaučiu uždegimu, astma, LOPL, laringitu, užkimimu ir otitu nebuvo statistiškai reikšmingos [9]. JAV atliktos kohortinès suaugusių žmoniu studijos parodè, kad GERL simptomai kartą per ménesị būna beveik 50 proc. suaugusiujuc, o kartą per savaitę - beveik 20 proc. Jų duomenimis, 21-41 proc. létinio kosulio atveju susiję su GERL [10]. Sistemine apžvalga, kuriai naudoti apžvalginiai straipsniai iš Bendrosios praktikos tyrimų duomenu bazès (angl. General Practice Research Database) [11], nustatyta, kad 1996 metais GERL dažnumas pirminès sveikatos priežiūros grandyje buvo 4,5 nauju atvejuc 1000 gyventoju per metus, o GERL diagnozè buvo susijusi su padidejusia kitu ligų, ìskaitant ir lètinį kosulį, rizika. Dideli paplitimą sąlygojo tiek fiziologiniai veiksniai, tiek ir patologinès būklès. Gerai žinoma [12], kad sveikiems ir ser- gantiesiems GERL refliukso epizodus salygoja tranzitorinè apatinès stemplès dalies relaksacija (TASR). Detaliai veiksniai, turintys ittakos apatinio stemplès rauko (ASR) funkcijai kontroliuoti, bus nagrinejami toliau šiame straipsnyje. Reikètu pabrèžti, kad fiziologiniai veiksniai, pavyzdžiui, dvikojų stemplès ir skrandžio jungties anatomijos ypatumai, gravitacinès jègos, sukeltos stovimos dvikojuc padèties, balso atsiradimo poveikis ASR funkcijai, gali skatinti refliukso epizodus ir su refliuksu susijusius stemplès ir ne stemplès simptomus. Kitaip nei keturkoju, kuriu stemplè jungiasi su skrandžiu $90^{\circ}$ kampu, dvikoju gastroezofaginè jungtis yra J formos (1 pav.), todèl stemple jungiasi su skrandžiu išilgai vertikalios linijos. Spejama, kad skirtinga dvikoju ir keturkojuc gastroezofaginès jungties anatomija ir turi itakos refliukso atsiradimui. Tikriausiai keturkoju $90^{\circ}$ jungtis tarp stemplès ir skrandžio yra daug veiksmingesnis fiziologinis barjeras refliuksui nei dvikojų vertikali gastroezofaginès jungties padetis. Kita vertus, dvikojų stovima padètis gali iš dalies apsaugoti nuo skrandžio turinio refliukso ị stemplę dèl gravitacinių jègų (1 pav.).

ASR yra fiziologinis raukas, $3-4 \mathrm{~cm}$ toniškai susitraukiančių lygiųjų raumenu plotas stemplès distaliniame gale [12]. Anatomiškai ši zona labiausiai atitinka distalinę stemplès dali ir yra 2-3 kartus storesnè nei proksimaliné stemplès siena. Diafragmos kojyčių skai- 


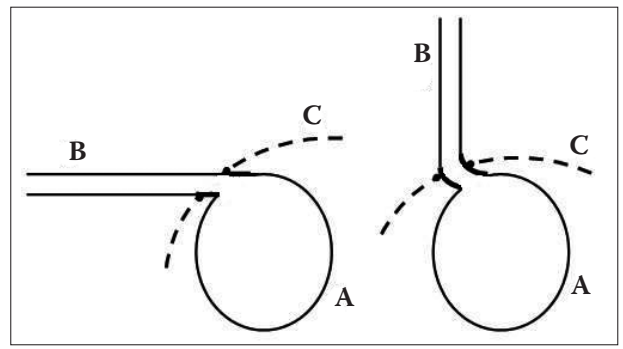

1 pav. KETURKOJŲ IR DVIKOJŲ GASTROEZOFAGINĖS JUNGTIES SCHEMA

$90^{\circ}$ keturkojy jungtis ir gravitacinis gradientas dèl vertikalios dvikoju padèties gali būti refliukso epizodu atsiradimą lemiantys veiksniai. A - skrandis; B - stemplè; C - diafragma (punktyriné linija).

dulos, kurios apgaubia ASR distalinėje stemplès dalyje, jungiasi su ASR per frenoezofagini raištị. Diafragmos susitraukimai padidina vidini slėgi pilvo ertmèje, tačiau tuo pat metu užkerta kelią skrandžio turinio refliuksui stemplę, perduodant diafragmos raumenų tonusą stemplei, ir taip padideja jungties spaudimas. Kai diafragma dalyvauja atliekant kitas funkcijas, pavyzdžiui, išgaunant balsą, jos įtaka jungties spaudimui sumažèja, todẻl gali ivykti refliukas. Fonacija yra išskirtine žmoniu savybè. Sis ypatumas paaiškina didelị refliukso dažnumą žmonių populiacijoje ir dažną refliuksinio kosulio pablogejjimą kalbant [13].

\section{REFLIUKSAS IR KOSULYS: PRIEŽASTIS AR SĄSAJA}

Gerai žinoma, kad stempliniai ir nestempliniai refliukso simptomai dažnai pasireiškia pacientams, kurie skundžiasi švokštimu ar lėtiniu kosuliu. Tačiau nèra aišku, ar respiracinius simptomus ir refliuksą sieja priežastinis ryšys ar tarpusavio sąveika. Respiratologų ir gastroenterologų draugijų gairès apie suaugusiųjų kvėpavimo takų simptomų ir refliukso tarpusavio ryši yra prieštaringos. Paprastai gastroenterologai nelinkę susieti viršutinių kvèpavimo takų simptomų su GERL $[5,6,14]$ Kai kuriose gairèse teigiama, kad „kosulys, švokštimas, užkimimas ar gerklès skausmas gali atsirasti refliuksa patiriantiems asmenims ir yra atsitiktiniai. Nera aišku, kokia refliukso reikšmè šiems nespecifiniams simptomams pasireikšti, tačiau jie būna tik mažumai asmenuূ“ [14]. Priešingai, respiratologų gairès dažniausiai patvirtina priežasties ir padarinio ryši $[3,4]$. Naujausiuose pranešimuose apie akivaizdu refliukso sukeltą kosuli teigiama, kad „neabejotinai, skrandžio turinio refliuksas yra svarbi lètinio kosulio priežastis. Kai kada tai galbūt svarbiausia priežastis“ [13]. Šis prieštaringas požiūris gali būti susijęs su skirtingu pulmonologu ir gastroenterologu pacientu kontingentu. Keletas mažu, vis dar neaprašytu studiju, atliktu mūsu universitetinèje ligoninèje, patvirtino tokią tikimybę. Lètiniu kosulio besiskundžiantiems asmenims, kurie kreipèsi į tretinio lygmens kosulio kliniką, refliukso simptomai, tipiniai ar netipiniai, buvo nustatyti 80 proc. atvejų (lentelè). Tuo tarpu lètinis kosulys nustatytas tik 16 proc. pacientų, kurie skundèsi refliukso simptomais ir kreipèsi ị funkcinių ligu gastroenterologijos skyriu (lentelè). Taigi pulmonologai ir gastroenterologai gydo skirtingų grupių pacientus: mažuma pacientu, kurie kreipiasi i gastroenterologus dèl refliukso, skundžiasi lètiniu kosuliu, tačiau dauguma pacientų, besiskundžiančių lètiniu kosuliu ir refliuksu gydomi kosulio klinikoje. Neginčijamai didelis refliukso dažnumas pacientų, kurie kreipiasi ì pulmonologus, grupejje paaiškina, kodèl labai paplitusi nuomonè, kad GER ir lètinis kosulys yra susiję

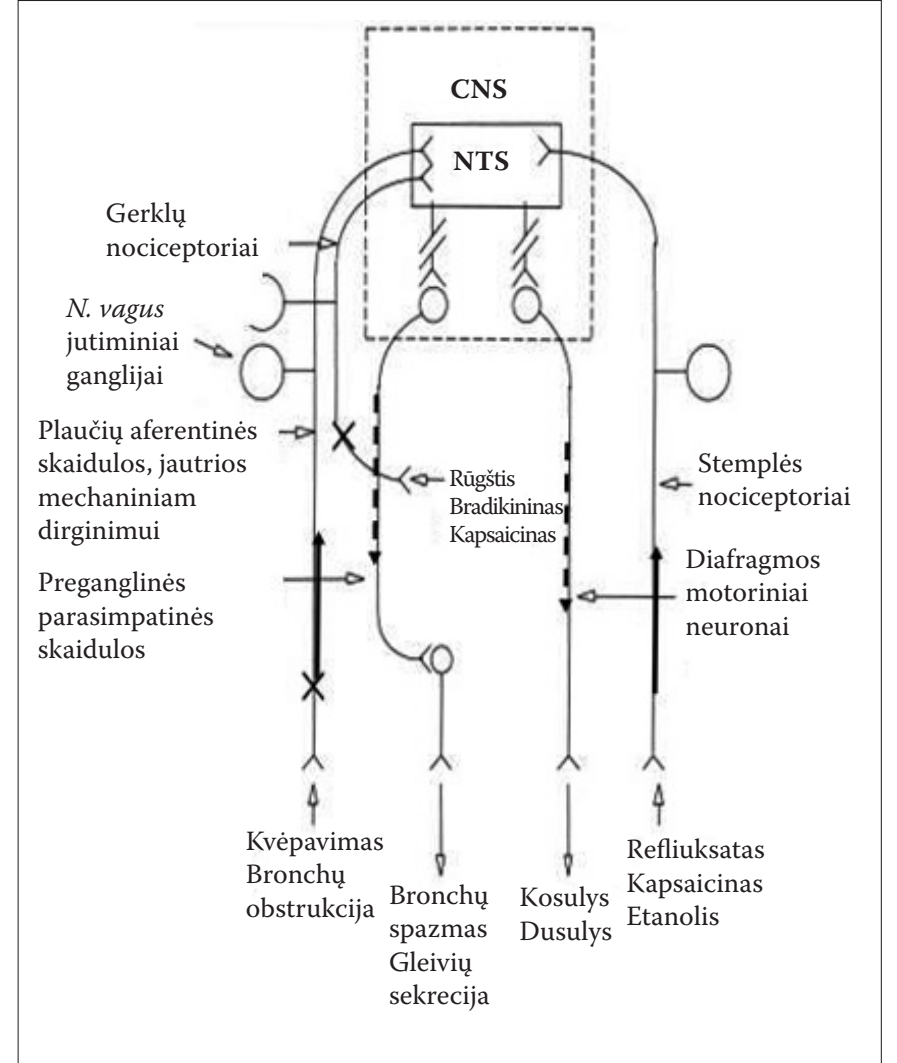

2 pav. SENSORINIŲ IR MOTORINIŲ SKAIDULŲ, DALYVAUJANČIŲ KYLANT KOSULIO REFLEKSUI, SCHEMA

Aferentinès skaidulos (ištisinés linijos), kylančios iš kvèpavimo taku ir viršutinès virškinamojo trakto dalies; eferentiniai nervai (punktyrines linijos), iskaitant klajokli nerva, inervuojantys bronchu lygiuosius raumenis, bronchy kraujagysles ir gleivinès liaukas, taip pat diafragminio nervo motorinès skaidulos inervuojančios diafragma.

priežastiniu ryšiu, tačiau patofiziologiniai šio ryšio mechanizmai galbūt niekada nebus iki galo išsiaiškinti.

\section{GALIMI REFLIUKSINIO KOSULIO MECHANIZMAI}

Priežastinius ryšius, De Principiis Naturae, Tomas Akvinietis apibūdino taip: „Ignis enim generat ignem, ergo ignis est causa efficiens inquantum generat"(,Ugnis sukelia ugni, todèl ugnis yra priežastis, nes ji pati ją sukuria“). Mažiausiai du skirtingi ir nesuderinami mechanizmai gali paaiškinti, kaip refliuksas gali „sukelti“ (sukeliančios priežastys) kosulį: tai skrandžio turinio aspiracija ir klajoklio nervo reguliuojamas stemplinis-tracheobronchinis refleksas [15]. Esant aspiracijai, dažnai pastebima refliukso sąlygotų virškinamojo trakto simptomų, kaip antai rèmuo, regurgitacija, rūgštumo skonis burnoje, odinofagija, dispepsija, naktinis prakaitavimas, krūtinès skausmas ir kąsnio gerklèje pojūtis [16]. Aspiracijai kartojantis, gali atsirasti šių faringolaringinių simptomų: disfonija, užkimimas, gerklès skausmas, taip pat dantenu uždegimas ir dantų emalio erozija [17]. Pacientai, kuriems vyksta aspiracija ị plaučius, gali skųstis krūtinès skausmu, dusuliu, skrepliavimu ir švokštimu [18]. Aspiracijos teorija visiškai atitinka Tomo Akviniečio filosofiją; visa mokslo bendruomenè neabejotinai sutinka, kad aspiracija yra kosulio priežastinis veiksnys ir šis mechanizmas daugiau nebus gvildenamas $[18,19]$. Tačiau ar aspiracija - vienintelis patogenezinis mechanizmas visais refliukso sukeltais kosulio atvejais? Carney su kolegomis, ištyrę 30 kosinčių pacientu indukuotus skreplius, kuriuose vertino lipiduc turinčius makrofagus, kaip aspiracijos žymenis, paneigé aspiraciją esant kosulio mechanizmu [20]. 
Lentelè. 25-IU PACIENTŲ, KURIE KREIPĖSI I TRETINIO LYGMENS KLINIKAS DE்L LĖTINIO KOSULIO AR GERL, DEMOGRAFINIAI DUOMENYS IR SIMPTOMAI

\begin{tabular}{|c|c|c|}
\hline & Kosulio klinika & $\begin{array}{c}\text { Gastroenterologijos } \\
\text { klinika }\end{array}$ \\
\hline Lytis (V/M) & $7 / 18$ & $14 / 11$ \\
\hline $\begin{array}{l}\text { Amžiaus vidurkis } \\
\text { (ribos) }\end{array}$ & $58,2(16-86) \mathrm{m}$ & $48,2(22-81) \mathrm{m}$ \\
\hline $\begin{array}{l}\text { Kosulio balų } \\
\text { vidurkis }(0-9)\end{array}$ & 6,1 & NA \\
\hline $\begin{array}{l}\text { Vidutinè } \\
\text { trukmé (ribos) }\end{array}$ & $8,9(0,5-40,0) \mathrm{m}$. & NA \\
\hline Stemplès simptomai & 20 proc. & 88 proc. \\
\hline GERL* & 80 proc. & 100 proc. \\
\hline Lètinis kosulys & 100 proc. & 16 proc. \\
\hline $\begin{array}{l}\text { Astmos } \\
\text { sindromas*\$ }\end{array}$ & 26 proc. & 8 proc. \\
\hline Rinosinusitas* & 13 proc. & 4 proc. \\
\hline
\end{tabular}

Vienas ar kartu su kitais simptomais; § jskaitant astma, kosulio astmą ir eozinofilinj bronchit NA - netirta.

Antras kosulio patogenezinis mechanizmas, esant GER, leidžia manyti, kad rūgštiniai/nerūgštiniai veiksniai, dirgindami stemplès gleivinę, refleksiškai sukelia kosulį. Gerai žinoma, kad stemplès jutiminiai nervai reaguoja ị stemplès gleivinès dirginimą rūgščiu turiniu. Pavyzdžiui, Irwino ir bendradarbių atlikti tyrimai [21], naudojant dvikanali pH matuokli, parodè, kad kosuli sukelia proksimalinès ir distalinès stemplès gleivinès dirginimas rūgštimi. Ing su kolegomis [22] nustaté, kad pacientams kosulys daug dažniau pasireiškè, kai distalinè stemplès dalis buvo dirginama rūgštimi nei fiziologiniu druskos tirpalu. Šis rūgščių sukeltas kosulys gali būti blokuojamas lidokaino infuzijomis ị distalinę stemplès dali [22]. Tačiau stemplès dirginimas rūgščiu turiniu nèra vienintelè kosulio priežastis esant GER. Sutrikusi stemplès motorika taip pat gali būti svarbus veiksnys „stemplinio“ kosulio patogenezèje [23]

Tyrimai rodo, kad GER yra susijęs su kvèpavimo takų uždegimu. Todèl jis gali būti svarbus respiracinių sutrikimų, pavyzdžiui, astmos priepuolio, priežastiniu veiksniu [24, 24]. Čia svarbiausią vaidmenị vaidina klajoklio nervo reguliuojamas neurogeninis uždegimas [26]. Tokią prielaidą patvirtina tai, kad sergantiesiems astma ir refliuksiniu kosuliu besiskundžiantiems asmenims kvėpavimo takuose nustatytas padidejjęs tachikininų kiekis. Tai rodo, kad šių asmenų kvėpavimo takų juntamųju nervų aktyvumas yra padidèjęs [27].

Daugelis pacientų, patiriančių GER, niekada nekosti [5] (lentelè), GER ne visada sukelia kosuli. Todèl refliuksas nevisiškai atitinka Tomo Akviniečio būtiną sąlygą, kad būtu laikomas refleksinio kosulio „priežastiniu veiksniu“, o tai leidžia daryti prielaidą, kad refliukso sukeltas kosulys vargu ar yra refleksinis kosulys, netgi jei šis mechanizmas gali būti svarbus kai kuriomis aplinkybėmis.

Alternatyvus paaiškinimas, kodèl lètinio kosulio varginami asmenys dažnai skundžiasi ir refliuksui būdingais simptomais yra toks: rūgštus turinys, būdamas stempleje, sukelia funkcinius kosulio reflekso lanko pokyčius, provokuodamas juos bet kurioje šio reflekso lanko dalyje, tiksliau - kvèpavimo takų sensorinių nervų galūnèlių ir laidų perduodančiu impulsą i CNS; galbūt GER daro poveikị ir motorinèms nervinių skaidulų galūnèlèms, tačiau tai tik teorija, kuri nèra ịrodyta. Stemplès neuroanatominé sensorinè-motoriné inervacija, sąveika tarp klajoklio nervo skrandžio-stemplès ir kvėpavimo organų neuronų pailgosiose smegenyse pavaizduota 2 paveiksle.

Isijautrinimas - tai padidejęs aferentinio nervo aktyvumas nepakitusiam dirgikliui. İsijautrinimas gali kilti dviem pagrindiniais būdais: periferiniu ir centriniu [28]. Centrinis įsijautrinimas apibūdinamas kaip sutrikusi neurono funkcija, kuriai būdinga padidèjęs recepsinis laukas, sukeliantis spontaninị sužadinimą ar didesni sužadinimo dažnumą, arba jautrumas dirgikliui, kuris anksčiau nesukeldavo sujaudinimo [29]. Nugaros smegenyse centrinis įsijautrinimas atsiranda pats savaime kaip padidejęs posinapsinis jaudrumas antros eilès neuronų po stipraus aferentinių nocicepsinių skaiduluc stimuliavimo [29]. Taip antros eilès neuronu dirginimo slenkstis sumažèja, ir paprastai sužadinimo nesukeliantys dirgikliai gali šiuos neuronus aktyvinti [30]. Nèra visiškai aišku, ar centrinis įsijautrinimas sąlygoja padidejjusi kosulio reflekso jautrumą daugeliui pacientų, turinčiuc GER. Tačiau tokia tikimybè yra ir galbūt bus patvirtinta, kad stemplès jutiminiai nervai užsibaigia tuose pačiuose srityse, kurios priima impulsus iš kvėpavimo takų jutiminių nervų [31]. Vis dèlto kosulio refleksas yra disreguliuotas GER atvejais [16] Nèra aišku, ar šis kosulio reflekso reguliavimo sutrikimas ar įsijautrinimas kyla periferijoje ar CNS, ar ir ten, ir ten. Galbūt individualiais atvejais vyrauja viena ar kita įsijautrinimo forma, ir tai turi reikšmès konkrečioje klinikinejje situacijoje. Centrinis ìsijautrinimas negali būti suprantamas kaip priežastinis veiksnys per sè; jis mažina kosulio reflekso jautrumo slenkstị didindamas atsaką prieš tai neefektyviems dirgikliams [28, 29].

\section{COUGH AND GASTROESOPHAGEAL REFLUX: THE MECHANISMS.}

GIOVANNI A. FONTANA MD, FRCP

DEPARTMENT OF INTERNAL MEDICINE, SECTION OF IMMUNOALLERGOLOGY, RESPIRATORY MEDICINE, AND CELL THERAPY, UNIVERSITY OF FLORENCE, ITALY

Key words: cough, gastroesophageal reflux, mechanisms of reflux cough. Summary. Cough is the most common presenting complaint in adults seeking medical treatment in an ambulatory setting. Gastro-esophageal reflux (GER) of gastric contents into the esophagus occurs in virtually all normal subjects and most often causes no symptom or discomfort. However, when GER is accompanied by symptoms or discomfort, it becomes non-physiological and is termed gastro-esophageal reflux disease. It seems therefore that the coexistence of reflux and cough in many patients can likely be plained on the basis of different mechanisms some of which are obvious (i. e. aspiration) whilst others require confirmatory investigations. There is no doubt that aspiration or micro-aspiration of gastric content represent an effective cause of cough in a well-delineated minority of patients. In other instances, neurogenic mechanisms reflexly acting in response to esophageal acidification may result in airway changes and respiratory symptoms including cough. Central sensitization of the cough reflex in response to "chronic" acid or non-acid exposure of the esophageal mucosa in refluxers may represent an unifying mechanism that, although not causative, exerts an important facilitatory effect on the genesis of a hypertussive state.

\section{LITERATŨRA}

1. Morice AH, Fontana GA, Sovijarvi AR, Pistolesi M, Chung KF, Widdicombe J, O'Connell F, Geppetti P, Gronke L, De Jongste J, Belvisi M, Dicpinigaitis P, Fischer A, McGarvey L, Fokkens WJ, Kastelik J; ERS Task Force. The diagnosis and management of chronic cough. Eur Respir J 2004, 24(3): 481-492. 